\title{
Beneficial Effects of Quercetin on Obesity and Diabetes
}

\author{
Leixuri Aguirre, Noemi Arias, M. Teresa Macarulla, Ana Gracia and Maria P. Portillo*
}

Group Nutrition and Obesity, Dpt. Nutrition and Food Sciences, Faculty of Pharmacy, University of the Basque Country, Paseo de la Universidad, 7. 01006 Vitoria (Spain), RETIC PREDIMED, Instituto de Salud Carlos III, Spain

\begin{abstract}
Scientific research is constantly looking for new molecules that could be used as dietary functional ingredients in the fight against obesity and diabetes, two pathologies highly prevalent in Western societies. In this context, flavonoids represent a group of molecules of increasing interest. The major flavonoid is Quercetin, which belongs to the class called flavonols and is mainly found in apples, tea, onions, nuts, berries, cauliflower, cabbage and many other foods. It exhibits a wide range of biological functions including anticarcenogenic, anti-inflammatory and antiviral; it also inhibits lipid peroxidation, platelet aggregation and capillary permeability. This review focuses on the main effects of Quercetin on obesity and diabetes. The mechanisms of action explaining the effects of Quercetin on these two metabolic disturbances are also considered. Good perspectives have been opened for Quercetin, according to the results obtained either in cell cultures or in animal models. Nevertheless, further studies are needed to better characterize the mechanisms of action underlying the beneficial effects of this flavonoid on these pathologies. Moreover, the body fat-lowering effect and the improvement of glucose homeostasis need to be confirmed in humans. Animal studies have consistently failed to demonstrate adverse effects caused by Quercetin. In contrast, due to inhibitory effect of Quercetin in cytochrome P450, interactions with drugs can be taken into account when they are administered at the same time than Quercetin.
\end{abstract}

Keywords: Quercetin, obesity, diabetes, insulin resistance, cell cultures and animal models.

\section{INTRODUCTION}

Flavonoids belong to a group of natural substances which have a variable phenolic structure and are found in fruits, vegetables, tea and wine. These natural foods were known for their beneficial effects on health long before flavonoids were isolated as the effective compounds. Flavonoids have a basic chemical structure of diphenylpropanes (C6-C3-C6) and are most often found attached to sugar (glycosides), but they can be aglycones, as Quercetin is, consisting of 3 rings and 5 hydroxil groups (Fig. 1). Average daily intake of polyphenols varies in the range of $10-100 \mathrm{mg}$ depending of eating habits [1]. Table 1 shows the foods in which Quercetin is mainly found [2].

It has been reported that Quercetin exhibits a wide range of biological functions including anticarcinogenic, antiinflammatory, antiviral activities. Moreover, it inhibits lipid peroxidation, platelet aggregation and capillary permeability. However, a major concern about this molecule is its poor oral bioavailability, which primarily depends on sugar moiety [3]. Most Quercetin is present in plants as hydrophilic glycosides that are not easily absorbed directly. After hydrolysis of the glycosides, the absorption of Quercetin aglycone is estimated to be as high as $65-81 \%$ [4].

This review focuses on the main effects of Quercetin on obesity and diabetes, a metabolic condition associated very often to obesity (Tables 2-5). The mechanisms of

*Address correspondence to this author at the Dpt. Nutrición y Bromatología, Facultad de Farmacia, Paseo de la Universidad, 7, 01006 Vitoria, España; Tel: +34-945-013067; Fax: +34-945-013014;

E-mail: mariapuy.portillo@ehu.es
Table 1. Amount of Quercetin in Selected Food (Mangels et al., 1993)

\begin{tabular}{|l|c|}
\hline Food & Quercetin (mg/100 g) \\
\hline \hline Brocoli, raw & 2.8 \\
\hline Carrots, raw & 0.4 \\
\hline Celery, raw & 3.5 \\
\hline Cocoa powder & 20.1 \\
\hline Cranberrries, raw & 14.0 \\
\hline Kale, raw & 5.1 \\
\hline Looseleaf lettuce raw & 2.0 \\
\hline Lingonberries, raw & 11.3 \\
\hline Onions raw & 22.6 \\
\hline Ripe tomatoes & 0.5 \\
\hline
\end{tabular}<smiles>O=c1c(O)c(-c2ccc(O)c(O)c2)oc2cc(O)cc(O)c12</smiles>

Fig. (1). Structure of Quercetin. 
Table 2. In Vitro Studies Showing the Effects of Quercetin on Adipocytes

\begin{tabular}{|c|c|c|c|c|}
\hline Authors/Year & Cell Culture Type & Dose & Effect & Mechanism \\
\hline $\begin{array}{l}\text { Kuppusamy } \\
\text { \& Das (1992) }\end{array}$ & $\begin{array}{l}\text { Adipocytes from epididymal } \\
\text { adipose tissue of male Wistar rats } \\
(180-230 \mathrm{~g})\end{array}$ & $30-50 \mu \mathrm{M}$ & - Stimulation of lipolysis. & - Inhibition of PDE. \\
\hline $\begin{array}{l}\text { Motoyashiki } \\
\text { et al. (1996) }\end{array}$ & $\begin{array}{l}\text { Adipocytes from epididymal } \\
\text { adipose tissue of male Wistar rats } \\
(200-220 \mathrm{~g})\end{array}$ & $100-500 \mu \mathrm{M}$ & $\begin{array}{l}\text { - Inhibition of the Vanadate- } \\
\text { increasing effect on LPL activity }\end{array}$ & \\
\hline $\begin{array}{l}\text { Hsu \&Yen } \\
(2006)\end{array}$ & 3T3-L1 Adipocytes & $50-250 \mu \mathrm{M}$ & - Induction of apoptosis. & $\begin{array}{l}\text { Decrease expression in PARP, } \\
\text { Bcl-2, Bax, and Bak proteins } \\
\text { - Increase expression and } \\
\text { activity of caspase } 3\end{array}$ \\
\hline $\begin{array}{l}\text { Ohkoshi et al. } \\
\text { (2007) }\end{array}$ & $\begin{array}{l}\text { Adipocytes from subcutaneous } \\
\text { and visceral adipose tissue } \\
\text { of female }(\mathrm{C} 5 \mathrm{BL} / 6 \mathrm{~J}) \text { mice } \\
\text { ( } 5 \text { weeks old })\end{array}$ & $100 \mu \mathrm{M}$ & & $\begin{array}{l}\text { - Stimulation of lipolysis of } \\
\text { visceral adipose tissue. }\end{array}$ \\
\hline $\begin{array}{l}\text { Ahn et al. } \\
(2008)\end{array}$ & 3T3-L1 Adipocytes & $10-100 \mu \mathrm{M}$ & $\begin{array}{l}\text { - Induction of adipogenesis. } \\
\text { - Inhibition of de novo lipogenesis }\end{array}$ & $\begin{array}{l}\text { Decrease in SRBP-1, C/EBP } \alpha \\
\text { and PPAR } \gamma \text { mRNA expression } \\
\text { - Decrease in SRBP-1 and FAS } \\
\text { mRNA } \\
\text { - Increase in ACC phosphorylation }\end{array}$ \\
\hline $\begin{array}{l}\text { Yang et al. } \\
\text { (2008) }\end{array}$ & $\begin{array}{l}\text { 3T3-L1 mouse embryo } \\
\text { fibroblasts }\end{array}$ & $12.5-100 \mu \mathrm{M}$ & - Increase in apoptosis & \\
\hline
\end{tabular}

Table 3. In Vivo Studies Showing the Effects of Quercetin on Body Weight and Body Fat

\begin{tabular}{|c|c|c|c|c|c|}
\hline Authors/Year & Animal model & Dose & Time & Effect & Mechanism \\
\hline $\begin{array}{l}\text { Steward et al. } \\
\text { (2008) }\end{array}$ & Male C57BL/6J mice & $8 \mathrm{~g} / \mathrm{kg}$ diet & 3 and 8 weeks & $\begin{array}{l}\text { - No effects on body weight } \\
\text { or body fat. }\end{array}$ & $\begin{array}{l}\text { Transient increase in } \\
\text { energy expenditure } \\
\text { at } 3 \text { weeks that } \\
\text { disappears at } 8 \text { weeks }\end{array}$ \\
\hline $\begin{array}{l}\text { Rivera et al. } \\
\text { (2008) }\end{array}$ & $\begin{array}{l}\text { Male Zucker rat } \\
\text { (13 weeks old) }\end{array}$ & $10 \mathrm{mg} / \mathrm{kg} \mathrm{BW} / \mathrm{d}$ & 10 weeks & - Decrease in body weight & \\
\hline $\begin{array}{l}\text { Elberg et al. } \\
\text { (2009) }\end{array}$ & $\begin{array}{l}\text { Male and female with a } \\
\text { BMI } 25-35 \mathrm{~kg} / \mathrm{m}^{2}\end{array}$ & $150 \mathrm{mg} / \mathrm{d}$ & 6 weeks & - No effect on body weight & \\
\hline $\begin{array}{l}\text { Liang et al. } \\
\text { (2009) }\end{array}$ & $\begin{array}{l}\text { Male and female } \\
\text { C57BL/6J mice } \\
\text { ( } 6 \text { weeks old })\end{array}$ & 66 mg/kg BW/d & 4 weeks & $\begin{array}{l}\text { Protection against body } \\
\text { weight gain induced by } \\
\text { HF feeding. }\end{array}$ & \\
\hline $\begin{array}{l}\text { Wein et al. } \\
(2010)\end{array}$ & $\begin{array}{l}\text { Male Wistar rats } \\
(280 \mathrm{~g})\end{array}$ & $25 \mathrm{mg} / \mathrm{kg} \mathrm{BW} / \mathrm{d}$ & 4 weeks & $\begin{array}{l}\text { - Decrease in plasmatic TG } \\
\text { - } \quad \text { No effect on body weight }\end{array}$ & $\begin{array}{l}\text { Decrease in PPAR } \gamma \\
\text { mRNA in adipose tissue }\end{array}$ \\
\hline $\begin{array}{l}\text { Lai et al. } \\
\text { (2011) }\end{array}$ & $\begin{array}{l}\text { Ovariectomized rats } \\
\text { (12 weeks old) }\end{array}$ & $20-625 \mathrm{mg} / \mathrm{kg}$ & 8 weeks & $\begin{array}{l}\text { - Decrease in body weight } \\
\text { and adiposity }\end{array}$ & $\begin{array}{l}\text { - Increase in lipolysis } \\
\text { - Increase in oxidation of } \\
\text { fatty acids } \\
\text { - Decrease in adipogenesis. }\end{array}$ \\
\hline $\begin{array}{l}\text { Kim et al. } \\
(2011)\end{array}$ & $\begin{array}{l}\text { Male Sprague-Dawley } \\
\text { ( } 5 \text { weeks old) }\end{array}$ & $\begin{array}{l}100 \mathrm{mg} / \mathrm{kg} \\
\mathrm{BW} / \mathrm{d}\end{array}$ & 7 weeks & - No effects on body weight & \\
\hline
\end{tabular}


Table 4. In Vitro Studies Showing the Effect of Quercetin on Glucose Utilization

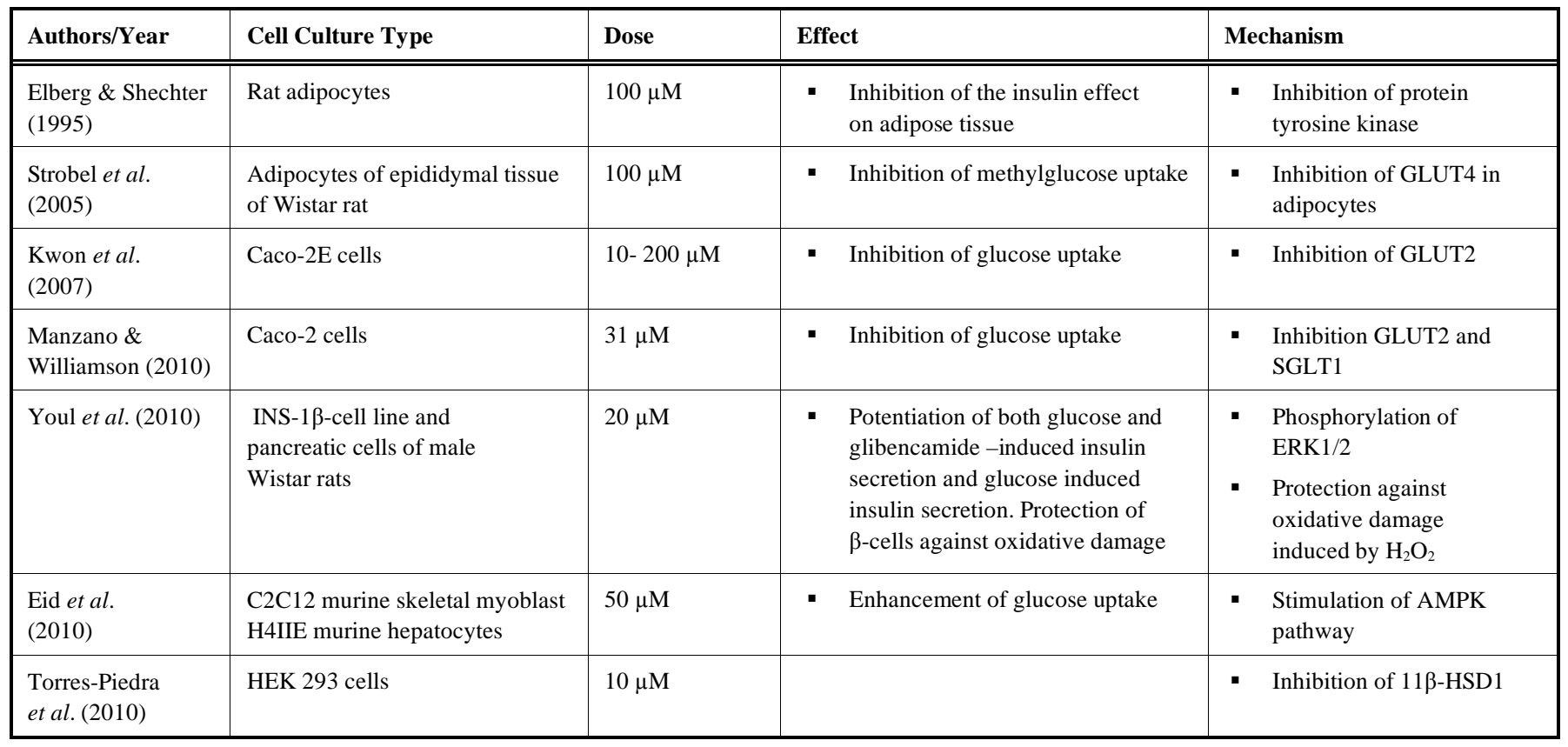

Table 5. In Vivo Studies Showing the Effect of Quercetin on Diabetes

\begin{tabular}{|c|c|c|c|c|c|}
\hline Authors/Year & Animal model & Dose & Time & Effect & Mechanism \\
\hline $\begin{array}{l}\text { Vessal et al. } \\
\text { (2003) }\end{array}$ & $\begin{array}{l}\text { Male Sprague-Dawley } \\
\text { STZ induced diabetes } \\
\text { rats }(200-220 \mathrm{~g})\end{array}$ & $\begin{array}{l}10 \text { and } 15 \\
\mathrm{mg} / \mathrm{kg} \mathrm{BW} / \mathrm{d}\end{array}$ & 10 days & $\begin{array}{l}\text { - Decrease in the fasting plasma glucose } \\
\text { - Improvement of glucose tolerance test } \\
\text { - Regeneration of the pancreatic islets }\end{array}$ & $\begin{array}{l}\text { - Increase in hepatic } \\
\text { glucokinase activity } \\
\text { - Increase in the number } \\
\text { of pancreatic islets }\end{array}$ \\
\hline $\begin{array}{l}\text { Coskun et al. } \\
(2005)\end{array}$ & $\begin{array}{l}\text { Male Wistar STZ } \\
\text { induced diabetes rats } \\
(200-250 \mathrm{~g})\end{array}$ & $\begin{array}{l}15 \mathrm{mg} / \mathrm{kg} \\
\mathrm{BW} / \mathrm{d}\end{array}$ & 4 weeks & $\begin{array}{l}\text { - Decrease in serum glucose and increase } \\
\text { in insulin in serum } \\
\text { - } \quad \begin{array}{l}\text { Protective effects against oxidative } \\
\text { damage }\end{array} \\
\text { - Preservation of pancreatic } \beta \text {-cell integrity }\end{array}$ & $\begin{array}{l}\text { - Decrease in MDA and } \\
\text { NO (decreasing lipid } \\
\text { peroxidation) } \\
\text { - Increase in antioxidant } \\
\text { enzymes activity: SOD, } \\
\text { GSHPx, CAT }\end{array}$ \\
\hline $\begin{array}{l}\text { Rivera et al. } \\
\text { (2008) }\end{array}$ & $\begin{array}{l}\text { Obese Zucker rats } \\
\text { (13 weeks old) }\end{array}$ & $\begin{array}{l}2 \text { and } 10 \\
\mathrm{mg} / \mathrm{kg} \mathrm{BW} / \mathrm{d}\end{array}$ & 10 weeks & - Decrease in hyperinsulinemia & \\
\hline $\begin{array}{l}\text { Kobori et al. } \\
(2009)\end{array}$ & $\begin{array}{l}\text { Male BALB/c STZ } \\
\text { induced diabetes mice } \\
\text { ( } 7 \text { weeks old) }\end{array}$ & $\begin{array}{l}0.1 \text { and } 0.5 \% \\
\text { diet }\end{array}$ & 2 weeks & $\begin{array}{l}\text { - Alleviation of diabetic symptoms } \\
\text { and liver injury } \\
\text { - Decrease in plasma glucose }\end{array}$ & $\begin{array}{l}\text { - Inhibition of Cdkn1a } \\
\text { expression in pancreas }\end{array}$ \\
\hline $\begin{array}{l}\text { Steward et al. } \\
(2009)\end{array}$ & $\begin{array}{l}\text { Male C57BL/6J mice } \\
\text { (6 weeks old) }\end{array}$ & $0.8 \%$ diet & $\begin{array}{l}3 \text { and } 8 \\
\text { weeks }\end{array}$ & $\begin{array}{l}\text { - At } 3 \text { weeks there is a insulin resistance } \\
\text { - At } 8 \text { weeks the insulin resistance } \\
\text { disappears }\end{array}$ & $\begin{array}{l}\text { Inhibition of insulin- } \\
\text { dependent activation of } \\
\text { PI-3K }\end{array}$ \\
\hline $\begin{array}{l}\text { Romero et al. } \\
(2010)\end{array}$ & $\begin{array}{l}\text { SHR and Wistar Kyoto } \\
\text { rats } \\
\text { ( } 24 \text { weeks old) }\end{array}$ & $\begin{array}{l}10 \mathrm{mg} / \mathrm{kg} \\
\mathrm{BW} / \mathrm{d}\end{array}$ & 4 weeks & $\begin{array}{l}\text { - No effects on serum glucose and insulin } \\
\text { levels and insulin resistance. }\end{array}$ & \\
\hline $\begin{array}{l}\text { Wein et al. } \\
(2010)\end{array}$ & $\begin{array}{l}\text { Male Wistar rats } \\
(280 \mathrm{~g})\end{array}$ & $\begin{array}{l}25 \mathrm{mg} / \mathrm{kg} \\
\mathrm{BW} / \mathrm{d}\end{array}$ & 4 weeks & - Decrease in hyperinsulinemia & $\begin{array}{l}\text { - Increase in adiponectin } \\
\text { levels } \\
\text { - Decrease in PPAR } \gamma \\
\text { mRNA in adipose tissue }\end{array}$ \\
\hline $\begin{array}{l}\text { Kim et al. } \\
(2011)\end{array}$ & $\begin{array}{l}\text { Male C57BL/ksJ- } d b / d b \\
\text { mice ( } 5 \text { weeks old) }\end{array}$ & $0.08 \%$ diet & 7 weeks & $\begin{array}{l}\text { - Decrease in fasting plasma glucose levels } \\
\text { and glycated hemoglobin }\end{array}$ & $\begin{array}{l}\text { Decrease the intestinal } \\
\text { maltose activity }\end{array}$ \\
\hline $\begin{array}{l}\text { Jung } \text { et al. } \\
\text { (2011) }\end{array}$ & $\begin{array}{l}\text { Male Sprague-Dawley } \\
\text { ( } 8 \text { weeks old) }\end{array}$ & $0-0.1 \%$ diet & 8 weeks & - No effect & \\
\hline
\end{tabular}


action explaining the effects of Quercetin on these two metabolic disturbances are also considered and scheduled in Figs (2 and $\mathbf{3}$ ).

\section{QUERCETIN AND OBESITY}

Obesity, defined as an excess of adipose tissue when body mass index is $\geq 30 \mathrm{~kg} / \mathrm{m}^{2}$, is due to an imbalance between energy intake and energy expenditure. Obesity is a major health problem in the industrialized world and it has reached epidemic proportions globally. The World Health Organization estimates that there are more than 1 billion overweight adults, of which at least 300 millions are obese [5]. Moreover, its prevalence is likely to increase as a result of changes in lifestyle, decreased physical activity, and socioeconomic development, among others. In addition, obesity is a complex multi-factorial and chronic disease that

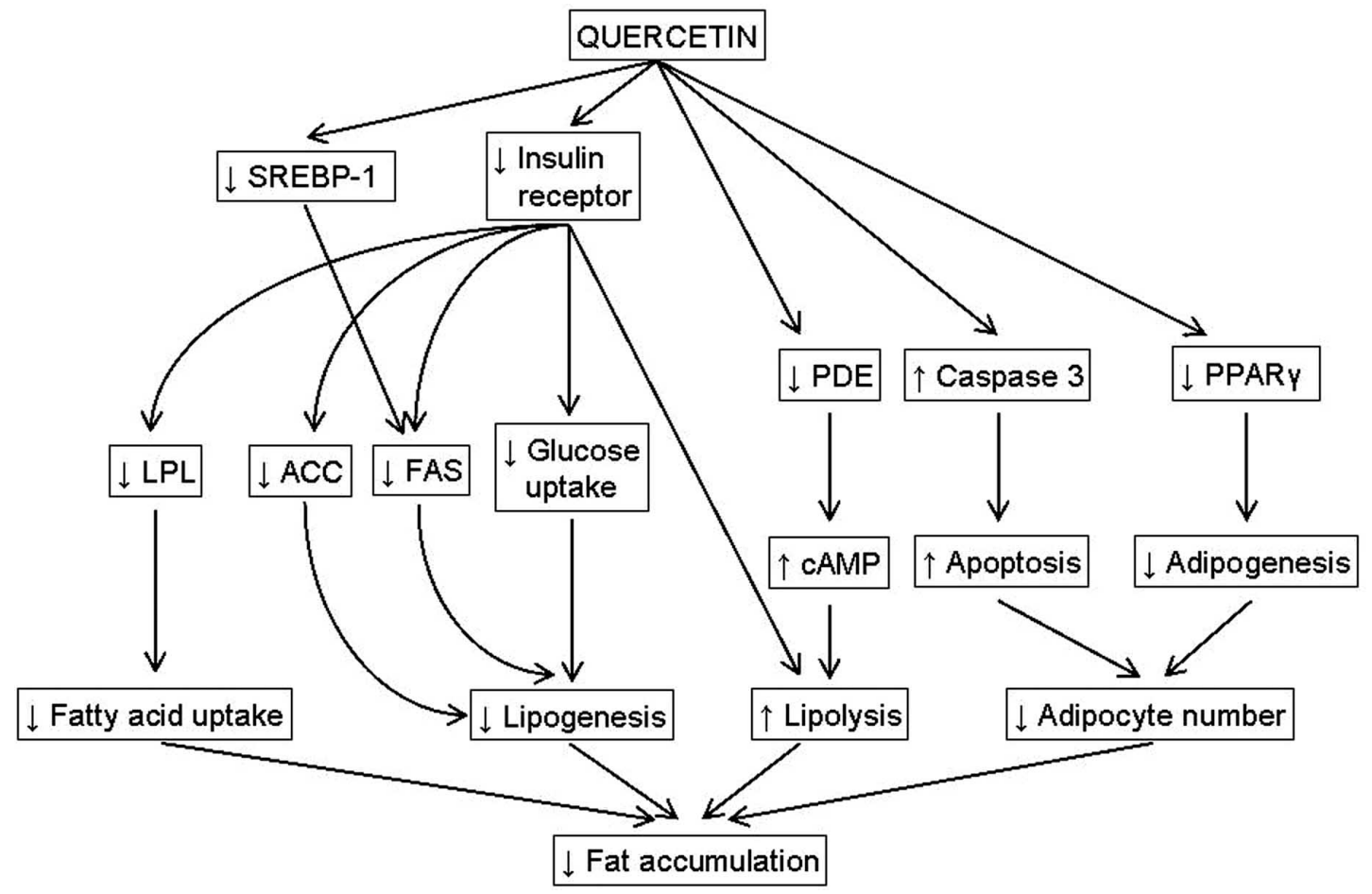

Fig. (2). Proposed mechanisms for body-fat lowering effects of Quercetin in adipose tissue.

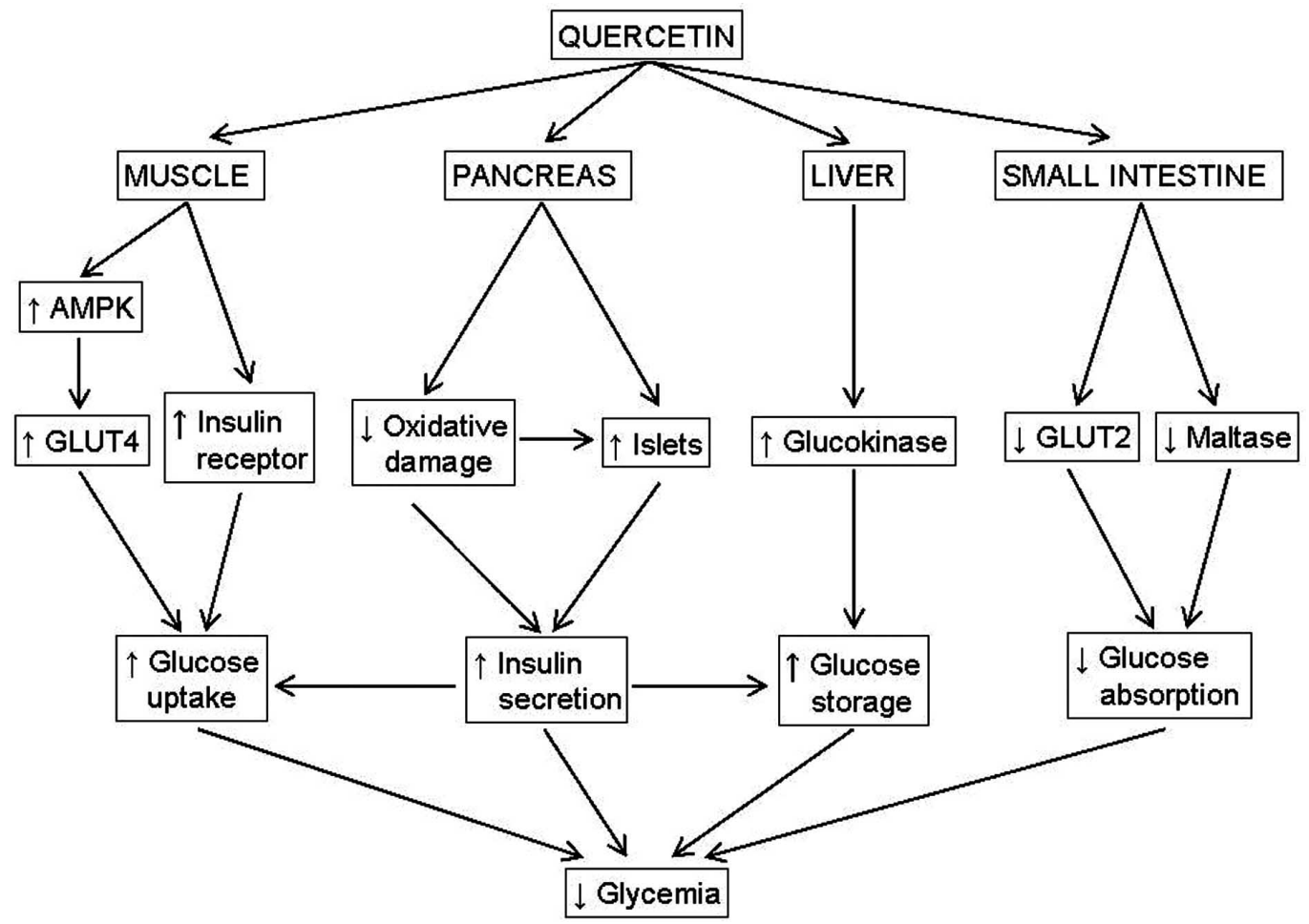

Fig. (3). Proposed mechanisms for anti-diabetic effects of Quercetin. 
is considered to be a risk factor for the genesis or development of various diseases including hypertension, type 2 diabetes, coronary heart disease, cancer, respiratory complications and osteoarthritis. Despite current intensive efforts to reduce obesity by diet, exercise, education, drug therapies and surgery, an effective long-term solution to this problem has yet to be provided.

Scientific research is constantly looking for new molecules that could be used as dietary functional ingredients in the fight against overweight and obesity; as in the case of flavonoids.

\section{In Vitro Studies}

The first studies addressing the potential anti-obesity action of Quercetin were carried out in vitro, mainly by using cells from adipose tissue and the 3T3-L1 cell line. The incubation of these cells with Quercetin led to a reduction in triacylglycerol content.

Apart from the indirect effects of Quercetin in lipogenesis via insulin, this flavonoid can also inhibit this metabolic pathway by acting directly on the expression of genes controlling this metabolic route. Ahn et al., [6] showed that Quercetin decreased the expression of Sterol Regulatory Element-Binding Proteins (SREBP)-1 and Fatty Acid Synthase (FAS), and by increasing Acetyl-CoA Carboxilasa (ACC) phosphorylation (Fig. 2).

Moreover, Motoyashiki et al., [7] described Quercetin to be a potent inhibitor of the stimulating effect of vanadate on lipoprotein lipase (LPL) activity. Vanadate shows insulinmimetic effects, such as increases in LPL and suppression of hormone-dependent lipolysis, in isolated rat adipocytes. Consequently, the inhibition of vanadate action leads to inhibition of LPL and thus to the incorporation of fatty acids which circulate as triacylglcyerols in lipoproteins to adipocyte triacylglycerols (Fig. 2).

Besides the effects on metabolic pathway involved in triacylglycerol accumulation, Quercetin can also stimulate lipid mobilization. Kuppusamy \& Das [8] described that Quercetin induced a dose- and time-dependent increase in lipolysis, which was synergic with epinephrine-induced lipolysis. This flavonoid produces a competitive phosphodiesterase (PDE) inhibition (Fig. 2). The competitive nature of the kinetics suggests that Quercetin could compete with cAMP for the same binding sites in the adipocyte PDE, thus increasing the concentration of cAMP, the molecule that activates protein kinase A (PKA), which in turn activates the hormone sensitive lipase (HSL).

The mechanisms of action described above justify the reduction in adipocyte triacylglycerol content induced by Quercetin. In addition, this flavonoid can also reduce the number of adipocytes, either by decreasing adipogenesis or increasing apoptosis (Fig. 2). Ahn et al., [6] demonstrated that Quercetin attenuated adipogenesis as a consequence of the decrease in the expression of CCAAT/Enhancer Binding Protein $\alpha(\mathrm{C} / \mathrm{EBP} \alpha)$, and Peroxisome Proliferator-Activated Receptor $\gamma$ (PPAR $\gamma$ ).

Hsu and Yen [9] described an increase in adipocyte apoptosis due to a down-regulation of PARP (PARP is a protein that has several roles in cellular processes, most notably in DNA repair and programmed cell death), Bcl-2 proteins (apoptosis regulator proteins), Bax, and $\mathrm{Bak}$ proteins. The activation of caspase- 3 and 9 , as well as the inhibition of adenosine monophosphate-activated protein kinase (AMPK) pathway, also play a role in the induction of apoptosis [6].

\section{In Vivo Studies}

The first study carried out with animals was reported by Steward et al. [10]. In this study C57BL/6J mice were fed on a high-fat diet (HFD) supplemented with Quercetin $(0.8 \%)$ for 3 and 8 weeks. Dietary supplementation with this molecule produced a transient ( 3 weeks) increase in energy expenditure (measured by indirect calorimetry), which was not detected after 8 weeks. A decrease in circulating Quercetin concentration between 3 and 8 weeks suggested a metabolic adaptation. Moreover, Quercetin, at the levels provided, was effective in reducing circulating markers of inflammation (IFN $\gamma$, TNF $\alpha$, IL1 and IL4) after 8 weeks of treatment.

In another study, Rivera et al., [11] analysed the effect of a chronic administration of Quercetin ( 2 or $20 \mathrm{mg} / \mathrm{kg}$ body weight/d) in obese Zucker rats (a model of genetic obesity). In good accordance with Steward et al., [10], final body weight was decreased. Both doses of Quercetin improved dyslipidemia, hypertension, and hyperinsulinemia, but only the high dose produced antiinflammatory effects in visceral adipose tissue.

Using C57BL/6J mice several authors have found reductions in body fat induced by Quercetin treatment. Liang et al. [12] reported that mice fed on a HFD supplemented with Quercetin $(66 \mathrm{mg} / \mathrm{kg}$ body weight $/ \mathrm{d})$ were protected against weight gain induced by the diet. Moreover, Ohkoshi et al. [13] showed a decrease in visceral and subcutaneous adipose tissue. Kobori et al., [14] reported that chronic dietary intake of Quercetin reduced body weight gain, as well as visceral and liver fat accumulation, and improved systemic parameters related to metabolic syndrome (hyperglycemia, hyperinsulinemia and dyslipidemia), probably by decreasing oxidative stress and increasing PPAR $\alpha$ expression. Moreover, Quercetin suppressed the expression of PPAR $\gamma$ and CD36, as well as SREBP-1c and its target fatty acid synthase (FAS) in the liver. The reduction in PPAR $\gamma$ expression suggests a reduction in adipogenesis, because genes involved in this process are controlled by this transcriptional factor. On the other hand, the reduction in SREBP expression, as well as the gene of the lipogenic enzyme FAS, suggest a reduction in the de novo lipogenesis in liver. Consequently, a reduced amount of triacylglycerols in plasma, coming from liver and available for adipose tissue uptake, can be suspected.

Nevertheless, not all the published studies have found positive effects of Quercetin on body weight and fat. In an experiment carried out with $d b / d b$ mice treated with Quercetin $(100 \mathrm{mg} / \mathrm{kg}$ of body weight/d) for 7 weeks the flavonoid led to a reduction in plasma glucose without changes in body weight [15]. In another experiment performed in Wistar rats treated with $25 \mathrm{mg}$ of Quercetin $/ \mathrm{kg}$ body weight/d and fed on HFD, body weight also remained unchanged [16]. 
Very little information has been reported concerning the effects of Quercetin on humans. The only published study shows that nutritional status (body weight, waist circumference, fat mass and fat-free mass) remained unchanged in subjects showing a body mass index between 25 and $35 \mathrm{~kg} / \mathrm{m}^{2}$, treated with $150 \mathrm{mg} / \mathrm{d}$ of Quercetin for 6 weeks [17].

\section{Quercetin Combinations}

In recent years, there has been increasing interest from Western Medicine in phytochemical combinations, which have been fundamental in traditional systems of herbal medicine. Combinations of some molecules may synergistically increase their therapeutic activity. Interestingly, in this context Quercetin can help to increase Resveratrol bioavailability. By the mean of in vitro and animal studies it has been shown that the polyphenol Resveratrol shows antiobesity properties [18]. However, a matter of concern is its low bioavailability due to the rapid and extensive metabolism in enterocytes and hepatocytes [19, 20]. It has been proved that some flavonoids are able to inhibit resveratrol metabolism. De Santi and co-workers observed that Quercetin inhibited sulfated metabolites production from Resveratrol, thus increasing the bioavailability of this polyphenol [21].

Apart from the interesting effects of Quercetin on Resveratrol bioavailability, in vitro studies have shown that these two polyphenols produce synergic effects. Yang et al., [22] showed that the combination of Resveratrol and Quercetin caused an enhanced increase in apoptosis in 3T3L1 adipocytes and in maturing preadipocytes inhibition compared to the predicted additive response. These results suggest that Resveratrol and Quercetin, especially in combination, may have a potential to be used for regulating the adipocyte cycle.

In the same line, Lai et al., [23] used a combination of Quercetin with other bioactive molecules (Resveratrol, vitamin D and Genistein) to find a common therapy for both obesity and osteoporosis. Mesenchymal stem cells are the precursors of both adipocytes and osteoblasts. In the aging population, differentiation to adipocytes dominates over the differentiation to osteoblasts in bone marrow. Thus, an inverse relationship exists between adipocytes and osteoblasts in the bone marrow. The above mentioned combination was tested in aged ovariectomized rats, an animal model for postmenopausal bone loss. Rats supplemented $2400 \mathrm{IU} / \mathrm{kg}$ vitamin D, 400, 2000 and $1040 \mathrm{mg} / \mathrm{kg}$ diet of Resveratrol, Quercetin and Genistein, respectively, reduced weight gain and adiposity without a change in food intake and increased bone density compared with each molecule administered alone.

\section{QUERCETIN AND DIABETES}

Diabetes mellitus is a chronic metabolic disorder which results in disturbances of carbohydrate, protein and lipid metabolism [24] due to either a lack of insulin secretion (type 1) or increased cellular resistance to insulin (type 2). Type 2 diabetes mellitus is one of the world's most common chronic diseases associated with changing lifestyles. It is characterized by hyperglycemia, peripheral resistance to the insulin action, and eventual destruction of insulin producing $\beta$-cells [25].

Under normal physiological conditions, blood glucose levels are tightly regulated by the secretion of insulin by specialized cells in pancreas Langerhans's islets. High blood glucose promotes insulin release from the $\beta$-cells of the islets. Insulin stimulates the uptake of glucose from the blood by different tissues such as muscle, kidney and adipose, promotes the storage of glucose in the liver as glycogen, and inhibits lipolysis in adipose tissue. The resulting depletion of blood glucose by the action of insulin in turn promotes the secretion of glucagon from the $\alpha$-cells in the pancreatic islets, which stimulates glycolysis in the liver and release of glucose back into the blood.

Obesity is a major predisposing factor in the development of Type 2 diabetes. Several hypotheses have been proposed to explain this link and during recent decades a great deal of attention has been given to the large amount of free fatty acids (FFA) received by liver skeletal muscle and pancreas (lipid toxicity) [26]. Moreover, in obese individuals, inflammatory molecules produced by adipose tissue play an important role in producing peripheral insulin resistance, as well as increasing damage to the insulin-producing $\beta$-cells [27].

Early treatment and prevention play a pivotal role in reducing burden of diabetes on the population. Lifestyle changes, such as exercising and dietary pattern modifications, are recommended, but these behavioural measures are difficult to maintain in the long term. The benefits of pharmaceutical factors to treat the disease aggressively in its early stages have been recommended, but medications may have unwanted side effects. In this context, flavonoids, among which Quercetin is one of the most commonly found in foods, has been reported to improve diabetic status [28].

\section{In Vitro Studies}

Studies carried out in cultured cells have shown that one of the mechanisms of action by which Quercetin improves glycaemic control is the reduction of intestinal glucose absorption at the level of glucose transporters (GLUT) (Fig. 3).

Kwon et al., [29] showed a robust inhibition of Quercetin in glucose and fructose transport by GLUT2 in Caco-2E intestinal cells. However, the two other major intestinal sugar transporters, GLUT5 and SGLT1, were unaffected by this flavonoid. Glucose transport was inhibited by Quercetin in a dose-dependent fashion and was complete at $200 \mu \mathrm{M}$ Quercetin dose.

In the same research line, Manzano \& Williamson [30] studied the effect of strawberry and apples juices, containing 87 and $41 \mu \mathrm{M}$ Quercetin respectively, on uptake and apical to basolateral transport of glucose using Caco-2 intestinal cells. Substantial inhibition of both uptake and transport was induced by extracts from both juices. The inhibition of GLUT2 was greater than that of SGLT1.

It has been also postulated that Quercetin blocks tyrosine kinase. Phosphorylation of the specific region of the $\beta$ subunit in insulin receptor (including Tyr-1158, Tyr-1161 and Tyr-1162) correlates with receptor tyrosine kinase 
activation and the propagation of the biological actions of the hormone [31]. The inhibition of protein tyrosine kinase was also observed by Elberg et al., [32].

Nevertheless, the effect of Quercetin in protein tyrosine kinase is controversial. Thus, Strobel et al., [33] reported that the inhibitory effect of Quercetin on glucose uptake was due to a direct action on the transporter GLUT4, rather than to an effect on cellular protein-tyrosine kinases.

Other authors have described that beneficial effects of Quercetin are due to its effects on the pancreas. Youl et al. [34], using the insulin-secreting cell line INS-1 $\beta$, determined the effects of Quercetin $(20 \mu \mathrm{M})$ on glucose- or glibenclamide-induced insulin secretion, as well as on $\beta$-cell dysfunctions induced by hydrogen peroxide $\left(\mathrm{H}_{2} \mathrm{O}_{2}\right)$. They observed that Quercetin potentiated both glucose and glibenclamide-induced insulin secretion. This effect was mediated by ERK1/2, a pathway that has been shown to participate in the regulation of glucose induced insulin secretion [35]. In order to confirm this effect in a more physiological model, the authors also used rat isolated islets of Langherans and similar results were obtained. Moreover, a protection against oxidative damage induced by $\mathrm{H}_{2} \mathrm{O}_{2}$ in $\beta$ cells was found (Fig. 3).

Another target for Quercetin seems to be AMPK pathway. The study carried out by Eid et al., [36] was aimed to elucidate the mechanism of action of the berries of Vaccinum vitis-idaea, traditionally used for the treatment of diabetes in several cultures throughout the world [37]. The authors analysed the effects of ten compounds present in berries on the glucose uptake in the $\mathrm{C} 2 \mathrm{C} 12$ murine skeletal myoblasts and H4IIE murine hepatocytes. They found that Quercetin-3$O$-glycoside and Quercetin aglycone were the two most active compounds in glucose uptake. This effect was insulin independent and seems to be mediated by AMPK, which facilitates the translocation of GLUT4 transporter [38] (Fig. 3).

Finally, Torres-Piedra et al., [39] in a study with HEK 293 cells suggested that the $11 \beta$-hydroxysteriod dehydrogenase type 1 (11 $\beta$-HSD1), which mediates glucocorticoid hormone action in human liver, adipose tissues and pancreatic $\beta$ cells, plays a role in the positive effects of Quercetin on glucose homeostasis. These authors demonstrated that Quercetin induced a 27\% inhibition of this enzyme at a concentration of $10 \mu \mathrm{M}$.

\section{In Vivo Studies}

Several studies have been carried out in diabetic animal models. Kim et al., [15] observed a reduction in serum glucose levels and blood glycated haemoglobin in C57BL/KsJ$d b-d b$ mice fed for 7 weeks on a diet supplemented with 0.08 $\%$ Quercetin, due to the inhibition of small intestine maltase activity, without changes in serum insulin levels (Fig. 3).

Vessal et al., [40] analysed the effects of Quercetin administrated intraperitonally (10 or $15 \mathrm{mg} / \mathrm{kg}$ body weight/d) for 10 days in control and streptozoticin-induced (STZ) type 1 diabetes rats. Although Quercetin had no effect on plasma glucose level in control animals, it significantly decreased this parameter in diabetic rats, in a dose dependent manner. Glucose tolerance curves of the diabetic treated animals were very similar to those of control rats. The increase of glu- cokinase activity induced by Quercetin plays an important role in this effect. This enzyme phosphorylates glucose and converts it into glucose-6-phosphate, a metabolite destined to glycogen synthesis (Fig. 3). Moreover, a significant increase in the number of pancreatic islets was seen in both normoglycemic and diabetic rats treated with Quercetin.

Coskun et al., [41] evaluated the possible protective effect of Quercetin against STZ-induced damage in $\beta$ cells. This flavonoid partially avoided the increase in serum glucose by decrease in serum insulin concentrations in these type 1 diabetic rats. These effects were due to the fact that Quercetin partially prevented degeneration of $\beta$-cells (Fig. 3).

Kobori et al., [42] proved that Quercetin included in the diet $(0.1-0.5 \%)$ led to the recovery of cell proliferation in mice showing type 1 diabetes induced by STZ. This beneficial effect was mediated by the inhibition of Cdknla, which regulates cell division by arresting the cell cycle.

Rivera et al., [43] analysed the effects of chronic administration of two doses of Quercetin on metabolic syndrome, including insulin resistance, in genetically obese Zucker rats. The supplementation was carried during 10 weeks with 2 or $10 \mathrm{mg} / \mathrm{kg}$ body weight/d. Both doses of Quercetin improved insulin resistance. No information concerning the mechanism of action underlying this effect was provided in this manuscript.

Wein et al., [16], in a study carried out on male Wistar rats fed on a HFD supplemented with $25 \mathrm{mg}$ Quercetin $/ \mathrm{kg}$ body weight/d, showed an increase in adiponectin expression in white adipose tissue and its circulating concentration, despite an inhibition of PPAR $\gamma$ expression. The authors concluded that the effects of Quercetin on adiponectin were PPAR $\gamma$ independent. Taking into account that adiponectin is an adipokine that facilitates insulin action, the authors proposed that the increase in adiponectin levels was involved in the improvement in insulin sensitivity induced by Quercetin.

Although, as described in this review, a great number of papers in the literature have reported positive effects of Quercetin on diabetes, specifically in Type 1 diabetic and genetically diabetic animals, there are also other studies that show either no effects or negative effects in other animal models of diabetes and/or insulin resistance.

Steward et al., [44] induced insulin resistance in rats by feeding animals on a HFD. These authors observed that Quercetin, at a dose of $0.8 \%$ in the diet exacerbated dietinduced insulin resistance at 3 weeks. After 8 weeks, insulin resistance in the Quercetin supplemented group was not worse, when compared with animal on HFD alone. These results suggest that the inhibitory effect of insulin signalling at 3 weeks was further eliminated by an adaptive increase hepatic metabolism and/or excretion of the compound between 3-8 weeks. At the doses used, Quercetin inhibited insulin-dependent activation of PI-3K.

To compare the benefits between supplementation with Quercetin and a food rich in Quercetin, Jung et al., [45] carried out an experiment with onion peel extract (OPE) in rats showing Type 2 diabetes. Animals were fed on HFD supplemented with either $1 \%$ OPE (containing $0.1 \%$ of Quercetin) or $0.1 \%$ of Quercetin alone for 8 weeks. While 
OPE administration led to significantly improved oral glucose tolerance, Quercetin alone did not have this effect.

Romero et al., [46] carried out a study in normotensive Wistar Kyoto (WKY) rats and in their counterparts, spontaneously hypertensive (SHR) rats In WKY the administration of Quercetin at $10 \mathrm{mg} / \mathrm{kg}$ body weight/d for 4 days did not alter serum glucose and insulin levels or insulin resistance. By contrast, in SHR rats, which show increased glucose and insulin levels, as well as insulin resistance when compared with the normotensive counterparts, Quercetin significantly increased fasting serum glucose. A weak non-significant increase in the homeostatic model assessment of insulin resistance was also noticed, indicating that there is a subtle negative effect of Quercetin on glucose metabolism.

\section{Toxicity of Quercetin}

In order to set out the potential applications of a biomolecules it is important to know about their safety. In this context, the first toxicity studies related to Quercetin were published in 1970. Bjeldanes \& Chang [47] found a positive mutagenic activity in the most standard strains of Salmonella. This mutagenic activity observed in bacterial test system was confirmed in eukaryotic cells, including yeast cells, at relatively high concentrations [48]. Additionally, in hamster and mouse cells, as well as in human lymphocytes, Quercetin exposure induced chromosomal aberrations, DNA single strand breaks and micronucleus formation [49].

The results of Quercetin-related mutagenicity/genotoxicity observed in vitro have not been confirmed by in vivo experiments. After oral administration to mice and rats, Quercetin did not induce any significant change in several mutagenicity/genotoxicity endpoints in somatic cells, in comparison with untreated controls [50-52]. Ambrose et al., [53] carried out an acute toxicity experiment in rabbits. A single intravenous dose of Quercetin (100-150 mg/kg body weight) was injected and no symptoms of toxicity were reported.

Quercetin has also been studied for its potential carcinogenicity in numerous long-term experimental animal studies, the majority of which indicated no evidences of significantly increased incidences of neoplasm formation related to its oral administration [53, 54, 55].

No variations were observed in a number of other standard toxicological parameters, clinical chemistry and organ weights in Swiss mice administered Quercetin at doses of 30, $300,3000 \mathrm{mg} / \mathrm{kg}$ body weight/day for a period of 28 days in comparison with a control group [56]. On the other hand, Quercetin is a strong antioxidant, which may have prooxidant properties under certain conditions. In vivo, several protective mechanisms act in concert to limit its potential to act a pro-oxidant/genotoxicant [57].

Taking into account that Quercetin is mainly excreted in urine, a study devoted to analyze potential toxicity in the renal system was carried out by the National Toxicology Program. An increased severity of chronic nephropathy, hyperplasia, and neoplasia of the renal tubular epithelium (causing primarily benign tumors of the renal tubular epithelium) was demonstrated in male, but not in female F344/N rats exposed to $40000 \mathrm{ppm}$ Quercetin in the diet ( $\approx 2000 \mathrm{mg} / \mathrm{kg}$ body weight/day). At lower levels, $1000 \mathrm{ppm}$ $(\approx 50 \mathrm{mg} / \mathrm{kg}$ bodyweight/day) and $10000 \mathrm{ppm}(\approx 500 \mathrm{mg} / \mathrm{kg}$ body weight/day), no statistically significant adverse effects (at $\mathrm{p} \leq 0.01$ ) were reported $[58,59]$.

Finally, in the early 1980 s, several studies reported the effects of flavonoids on the activity of hepatic cytochrome P450 (P450) enzymes [60]. Since then, the ability of flavonoids to inhibit isoforms of CYP450 has been extensively confirmed [61]. Cytochrome P450 (CYP) monooxygenases are probably the most important enzymes in hepatic drug metabolism, which is crucial for the elimination of many therapeutic drugs [62]. It has been published that Quercetin is a potent inhibitor of CYP2C8 [63, 64], CYP2C9 [65] and CYP3A4 [66] enzymes of the cytochrome P450 at concentrations lower than $50 \mu \mathrm{M}$.

The activity of this group of enzymes could determine the patient's response to drug therapy. The interactions between drugs and bioactive molecules could frequently arise when drugs are co-administered. The clinical significance of such interactions also depends on the disposition and toxicity profile of the drug being administered. In the case of cyclosporin, digoxin, indinavir, midazolam, simvastatin and some 1,4-dihydropyridine calcium antagonists, the inhibition of the cytochrome P450 (due to Quercetin intake) could carry out an elevated plasma concentrations with the toxic effects due to its accumulation in the organism $[67,68]$.

\section{CONCLUSIONS}

In the search for new molecules that could be used as dietary functional ingredients in obesity and diabetes, good perspectives have opened up for Quercetin, according to the results obtained either in cell cultures or in animal models. Nevertheless, further studies are needed to better characterize the mechanisms of action underlying the beneficial effects of this flavonoid on these pathologies. Moreover, the body fat-lowering effect and the improvement of glucose homeostasis need to be confirmed in humans.

Animal studies have consistently failed to demonstrate adverse effects caused by Quercetin. In contrast, due to inhibitory effect of Quercetin in cytochrome P450, interactions with drugs can be taken into account when they are administered at the same time than Quercetin.

\section{CONFLICT OF INTEREST}

None declared.

\section{ACKNOWLEDGEMENTS}

This study was supported by grants from the Ministerio de Ciencia e Innovación (AGL2011- 27406-ALI), Instituto de Salud Carlos III (RETIC PREDIMED) and Government of País Vasco (IT-386-10; CTP09/R5). N.A. is a recipient of a doctoral fellowship from the Government of País Vasco.
ABBREVIATIONS
$\mathrm{ACC}=$ Acetyl-CoA carboxilasa
AMPK $=$ Adenosine monophosphate-activated protein kinase
FAS $\quad=$ Fatty Acid Synthase
GLUT = Glucose transporter 


\begin{tabular}{|c|c|c|}
\hline HFD & $=$ & High-fat diet \\
\hline LPL & $=$ & Lipoprotein lipase \\
\hline OPE & $=$ & Onion peel extract \\
\hline PDE & $=$ & Phosphodiesterase \\
\hline $\operatorname{PPAR} \gamma$ & $=$ & Peroxisome Proliferator-Activated Receptors $\gamma$ \\
\hline SHR & $=$ & Spontaneously hypertensive rats \\
\hline SREBP & $=$ & Sterol Regulatory Element-Binding Proteins \\
\hline STZ & $=$ & Streptozotocin \\
\hline WKY & $=$ & Wistar Kyoto rats \\
\hline
\end{tabular}

\section{REFERENCES}

[1] Scalbert A, Williamson G. Dietary intake and bioavailability of polyphenols. J Nutr 2000; 130: S2073-85.

[2] Mangels AR, Holden JM, Beecher GR, et al. Caretenoide contents of fruits and vegetables: an evaluation of analytical data. Am Diet Assoc 1993; 93: 284-96.

[3] Graefe EU, Wittig J, Mueller S, et al. Pharmacokinetics and bioavailability of quercetin glycosides in humans. J Clin Pharmacol 2001; 41: 492-9.

[4] Walle T, Otake Y, Walle UK, Wilson FA. Quercetin glucosides are completely hydrolyzed in ileostomy patients before absorption. J Nutr 2000; 130: 2658- 61.

[5] World Health Organization, "Fact sheet: Obesity and overweight," http://www.who.int/hpr/gs.fs.obesity.shtml [accessed: 15 July 2011].

[6] Ahn J, Lee H, Suna K, Park J, Ha T. The anti-obesity effect of quercetin is mediated by the AMPK and MAPK signaling pathaways. Biochem Biophy Res 2008; 373: 545-9.

[7] Motoyashiki T, Morita T, Ueki H. Involvement of the rapid increase in cAMP content in the Vanadate-Stimulated Release of Lipoprotein Lipase activity from rat fat pad. Biol Pharm Bull 1996; 19: 1412-6.

[8] Kuppusamy UR, Das NP. Effects of flavonoids on cyclic AMP phosphodiesterase and lipid mobilezation in rat adipocytes. Biochem Pharma 1992; 44: 1307-15.

[9] Hsu CL, Yen GC. Induction of cell apoptosis in 3T3-L1 preadipocytes by flavonoids is associated with their antioxidant activity. Mol Nutr Food Res 2006; 50: 1072-9.

[10] Stewart LK, Soileau JL, Ribnicky D, et al. Quercetin transiently increases energy expenditure but persistently decreases circulating markers of inflammation in C57BL/6J mice fed a high-fat diet. Metabolism 2008; 57 (Suppl 1): S39-46.

[11] Rivera L, Morón R, Sánchez M, et al. Quercetin ameliorates metabolic syndrome and improves the inflammatory status in obese zucker rats. Obesity 2008; 16: 2081-7.

[12] Liang C, Oest ME, Prater ME. Intrauterine exposure to high saturated fat diet elevates risk of adult-onset chronic diseases in C57BL/6 Mice. Birth Defects Research (Part B) 2009; 86: 377-84.

[13] Ohkoshi E, Miyazaki H, Shindo K, et al. Constituents from the leaves of Nelumbo nucifera stimulate lipolysis in the white adipose tissue of mice. Planta Med 2007; 73: 1255-9.

[14] Kobori M, Masumoto S, Akimoto Y, Oike H. Chronic dietary intake of quercetin alleviates hepatic fat accumulation associated with consumption of a Western-style diet in C57/BL6J mice, Mol Nutr Food Res 2011; 55: 530-40.

[15] Kim JH, Kang MJ, Choi HN, et al. Quercetin attenuates fasting and postprandial hyperglycemia in animal models of diabetes mellitus. Nutr Res Pract 2011; 5(2): 107-11.

[16] Wein S, Behm N, Petersen RK, et al. Quercetin enhances adiponectin secretion by a PPAR $\gamma$ independent mechanism. Eur $\mathbf{J}$ Pharm Sci 2010; 41: 16-22.

[17] Egert S, Boesch-Saadatmandi C,Wolffram S, et al. Serum lipid and blood pressure responses to quercetin vary in overweight patients by apolipoprotein E genotype. J Nutr 2010; 140(2): 278-84.

[18] Szkudelska K, Szkudelski T. Resveratrol, obesity and diabetes. Eur J Pharmacol 2010; 635(1-3): 1-8.

[19] Walle T, Hsieh F, DeLegge MH, et al. High absorption but very low availability of oral resveratrol in humans. Drug Metab Dispos 2004; 32: 1377-82.
[20] Walle T. Biovailability of resveratrol. Ann N Y Acad Sci 2011; 1215: 9-15.

[21] De Santi C, Pietrabissa A, Mosca F, et al. Sulphation of resveratrol, a natural compound present in wine, and its inhibition by natural flavonoids. Xenobiotica 2000; 30: 857-66.

[22] Yang JY, Della-Fera MA, Rayalam S, et al. Enhanced inhibition of adipogenesis and induction of apoptosis in 3T3-L1 adipocytes with combinations of resveratrol and quercetin. Life Sci 2008; 82: 10329.

[23] Lai CY, Yang JY, Rayalam S, et al. Preventing Bone Loss and Weight Gain with Combinations of Vitamin D and Phytochemicals. J Med Food 2011 Jun 11. [Epub ahead of print]

[24] American Diabetes Association. Diagnosis and classification of diabetes melitus. Diabetes care 2011; 34: S62-9.

[25] Dandona P, Aljada A, Chaudhuri A, et al. Metabolic síndrome a comprehensive perspective based on interactions between obesity, diabetes and inflammation. Am Heart Assoc 2005; 111: 1448-54.

[26] Ouchi N, Parker JL, Lugus JJ, Walsh K. Adipokines in inflammation and metabolic disease. Nat Rev Immunol 2011; 11: 85-97.

[27] Bingley PJ, Mahon JL, Gale EA. Insulin resistance and progression to type 1diabetes in the European Nicotinamide Diabetes Intervention Trial (ENDIT). Diabetes Care 2007; 31: 146-50.

[28] Gregory S. Kelly ND. Quercetin. AMR 2011; 16: 2: 172-94.

[29] Kwon O, Eck P, Chen S, et al. Inhibition of the intestinal glucose transporter GLUT2 by flavonoids. FASEB J 2007; 21: 366-77.

[30] Manzano S, Williamson G. Polyphenols and phenolic acids from strawberry and apple decrease glucose uptake and transport by human intestinal Caco-2 cells. Mol Nutr Food Res 2010; 54: 1773-80.

[31] Rosen OM. After insulin binds. Science 1987; 237(4821): 1452-8.

[32] Elberg G, Jinping Li, Leibovitch A, Shechter Y. Non-receptor cytosolic protein tyrosine kinases from various rat tissues. Biochim Et Biophy Acta 1995; 1269: 299-306.

[33] Strobel P, Allard C, Pérez-Acle T, et al. Myricetin, quercetin and catechin-gallate inhibit glucose uptake in isolated rat adipocytes. Biochem J 2005; 386: 471-8.

[34] Youl E, Bardy G, Magous R, et al. Quercetin potentiates insulin secretion and protects INS-1 pancreatic b-cells against oxidative damage via the ERK1/2 pathway. BJP 2010; 161(4): 799-814.

[35] Longuet C, Broca C, Costes S, et al. Extracellularly regulated kinases $1 / 2$ (p44/42 mitogen-activated protein kinases) phosphorylate synapsin I and regulate insulin secretion in the MIN6 beta-cell line and islets of Langerhans. Endocrinology 2005; 146: 643-54.

[36] Eid HM, Martineau LC, Saleem A, et al. Stimulation of AMPactivated protein kinase and enhancement of basal glucose uptake in muscle cells by quercetin and quercetin glycosides, active principles of the antidiabetic medicinal plant Vaccinium vitis-idaea. Mol Nutr Food Res 2010; 54: 991-1003.

[37] Zazworsky D, Nelson Bolin J, Gaubeca VB. Handbook of Diabetes Management, Springer, New York, NY 2005.

[38] Santos JM, Ribeiro SB, Gaya AR, et al. Skeletal muscle pathways of contraction-enhanced glucose uptake. Int J Sports Med 2008; 29(10): 785-94.

[39] Torres-Piedra M, Ortiz-Andrade R, Villalobos-Molina R, et al. A comparative study of flavonoid analogues on streptozotocinenicotinamide induced diabetic rats: Quercetin as a potential antidiabetic agent acting via $11 \mathrm{~b}-\mathrm{Hydroxysteroid} \mathrm{dehydrogenase} \mathrm{type} 1$ inhibition. Eur J Med Chem 2010; 45: 2606-12.

[40] Vessal M, Hemmati M, Vasei M. Antidiabetic effects of quercetin in streptozocin-induced diabetic rats. Comp Biochem Physiol C: Comp Pharmacol Toxicol 2003; 135: 357-64.

[41] Coskun O, Kanter M, Korkmaz A, Oter S. Quercetin, a flavonoid antioxidant, prevents and protects streptozotocin-induced oxidative stress and $\beta$-cell damage in rat páncreas. Pharmacol Res 2005; 51: 117-23.

[42] Kobori M, Masumoto S, Akimoto Y, Takahashi Y. Dietary quercetin alleviates diabetic symptoms and reduces streptozotocininduced disturbance of hepatic gene expression in mice. Mol Nutr Food Res 2009; 53: 859-68.

[43] Rivera L, Morón R, Sánchez M, et al. Quercetin ameliorates metabolic syndrome and improves the inflammatory status in obese zucker rats. Obesity 2008; 16; 2081-7.

[44] Steward LK, Wang Z, Ribnicky D, et al. Failure of dietary quercetin to alter the temporal progression of insulin resistance among tissues of C57BL/6J mice during the development of diet-induced obesity. Diabetologia 2009; 52: 514-23. 
[45] Jung JY, Lim Y, Moon MS, et al. Onion peel extracts ameliorate hyperglycemia and insulin resistance in high fat diet/ streptozotocin-induced diabetic rats. Nutr Metab 2011; 8: 18.

[46] Romero M, Jiménez R, Hurtado B, et al. Lack of beneficial metabolic effects of quercetin in adult spontaneous hypertensive rats. Eur J Pharmacol 2010; 627: 242-50.

[47] Bjeldanes LF, Chang GW. Mutagenic activity of quercetin and related compounds. Science 1997; 197: 577-8.

[48] Hardigree AA, Epler JL. Comparative mutagenesis of plant flavonoids in microbial systems. Mutat Res 1978; 58: 231-9.

[49] Yoshida MA, Sasaki M, Sugimura K, Kawachi T. Cytogenetic effects of quercetin on cultured mammalian cells. Proc Jpn Acad Ser B 1980; 56: 443-7.

[50] MacGregor JT. Mutagenicity studies of flavonoids in vivo and in vitro. Toxicol Appl Pharmacol 1979; 48 : A47 (Abstract).

[51] Ngomuo AJ, Jones RS. Genotoxicity studies of quercetin and shikimate in vivo in the bone marrow of mice and gastric mucosal cells of rats. Vet Hum Toxicol 1996; 38: 176-80.

[52] Cierniak A, Papiez M, Kapiszewska M. Modulatory effect of quercetin on DNA damage, induced by etoposide in bone marrow cells and on changes in the activity of antioxidant enzymes in rats. Rocz Akad Med Bialymst 2004; 49: 167-9.

[53] Ambrose AM, Robbins DJ, DeEds F. Comparative toxicities of quercetin and quercitrin. J Am Pharm Assoc Sci Ed 1952; 41: $119-2$

[54] Saito D, Shirai A, Matsushima T, Sugimura T, Hirono I. Testof carcinogenicity of quercetin, a widely distributed mutagen in food. Teratog Carcinog Mutagen 1980; 1: 213-21.

[55] Morino K, Matsukara N, Kawachi T, Ohgaki H, Sugimura T, Hirono I. Carcinogenicity test of quercetin and rutin in goldenhamsters by oral administration. Carcinogenesis 1982; 3: 93-7.

[56] Ruiz MJ, Fernández M, Estela JM, Asensi M, Mañes J, Picó Y. Short-term oral toxicity of quercetin and pterostibene in Swiss mice. Toxicol Lett 2006; 164S: S1-324 (Abstract P22-15).

[57] Harwood M, Danielewska-Nikiel B, Borzelleca JF, Flamm GW, Williams GM, Lines TC. A critical review of the data related to the safety of quercetin and lack of evidence of in vivo toxicity, including lack of genotoxic/carcinogenic properties. Food Chem Toxicol 2007; 45: 2179-205.
[58] Dunnick JK, Hailey JR. Toxicity and carcinogenicity studies of quercetin, a natural component of foods. Fundam Appl Toxicol 1992; 19: 423-31.

[59] NTP, 1992. Toxicology and Carcinogenesis Studies of Quercetin (CAS No., 117-39-5) in F344/N Rats (Feed Study). NTP Technical Report Series, No. 409. National Toxicology Program (NTP), Research Triangle Park, North Carolina. Available from: <http:// ntp.niehs.nih.gov/ntp/htdocs/LT_rpts/tr409. pdf >.

[60] Buening MK, Chang RL, Huang MT, Fortner JG, Wood AW, Conney AH. Activation and inhibition of benzo(a) pyrene and aflatoxin B1 metabolism in human liver microsomes by naturally occurring flavonoids. Cancer Res 1981; 41: 67-72.

[61] Cermak R, Wolffram S. The potential of flavonoids to influence drug metabolism and pharmacokinetics by local gastrointestinal mechanisms. Curr Drug Metab 2006; 7: 729-44.

[62] KH Liu, MJ Kim, BH Jeon, et al. Inhibition of human cytochrome $\mathrm{P} 450$ isoforms and NADPH-CYP reductase in vitro by 15 herbal medicines, including Epimedii herbal. J Clin Pharm Ther 2006; 31: 83-91.

[63] Toda T, Eliasson E, Ask B, Inotsume N, Rane A. Roles of Different CYP Enzymes in the Formation of Specific Fluvastatin Metabolites by Human Liver Microsomes. Basic Clin Pharmacol Toxicol 2009; 105(5): 327-32.

[64] O'Donnell CJ, Grime K, Courtney P, Slee D, Riley RJ. The Development of a Cocktail CYP2B6, CYP2C8, and CYP3A5 Inhibition Assay and a Preliminary Assessment of Utility in a Drug Discovery Setting. Drug Metab Dispos 2007; 35: 381-5.

[65] Si D, Wang Y, Zhou IH, et al. Mechanism of CYP2C9 Inhibition by Flavones and Flavonols. Drug Metab Dispos 2009; 37: 629-34.

[66] Choi JS, Piao YJ, Kang KW. Effects of quercetin on the bioavailability of doxorubicin in rats: role of CYP3A4 and P-gp inhibition by quercetin. Arch Pharm Res 2011; 34(4): 607-13.

[67] Izzo AA. Drug interactions with St. John's wort (Hypericum perforatum): a review of the clinical evidence. Int J Clin Pharmacol Ther 2004; 42(3): 139-48.

[68] Henderson L, Yue QY, Bergquist C, Gerden B, Arlett P. St John's wort (Hypericum perforatum): drug interactions and clinical outcomes. Br J Clin Pharmacol 2002; 54(4): 349-56.

(C) Aguirre et al.; Licensee Bentham Open.

This is an open access article licensed under the terms of the Creative Commons Attribution Non-Commercial License (http://creativecommons. org/licenses/ by-nc/3. 0/) which permits unrestricted, non-commercial use, distribution and reproduction in any medium, provided the work is properly cited. 